ANUVA Volume 2 (3): 273-279, 2018

Copyright @2018, ISSN: 2598-3040 online

Available Online at: http://ejournal.undip.ac.id/index.php/anuva

\title{
Pengembangan Instrumen Pengukuran Kemampuan Literasi Informasi Berbasis Efikasi Diri (Self Efficacy)
}

\author{
Yanuar Yoga Prasetyawan ${ }^{1 *}$ \\ ${ }^{1}$ Program Studi Ilmu Perpustakaan, Fakultas Ilmu Budaya, Universitas Diponegoro, \\ Jl. Prof. Soedarto, SH, Kampus Undip Tembalang, Semarang, Indonesia 50275 \\ *Korespondensi: yanuaryoga@ live.undip.ac.id
}

\begin{abstract}
Information literacy is a set of abilities to determine the extent of information needed, access the needed information effectively and efficiently, evaluate information and its sources critically, incorporate selected information into one's knowledge base, use information effectively to accomplish a specific purpose, understand the economic, legal, and social issues surrounding the use of information, and access and use information ethically and legally. To find out these abilities, various measurement instruments were designed. Instruments that have been developed earlier by measuring cognitively the information literacy competencies. Next comes the premise that states that psychological factors in the form of self-efficacy also contribute to determining individual success in completing tasks.. Through this premise, arguments arise that self-efficacy can be approach to measure information literacy competencies. By adopting psychology discipline developed an alternative measurement of information literacy skills called SelfEfficacy Information Literacy.
\end{abstract}

Keyword: information literacy; competence assessment; self efficacy

\begin{abstract}
Abstrak
Literasi informasi merupakan kemampuan untuk menentukan informasi yang dibutuhkan, mengakses kebutuhan informasinya secara efektif dan efisien, mengevaluasi informasi dan sumber-sumber yang didapatkannya secara kritis, menggabungkan informasi yang dipilihnya menjadi sebuah landasan pengetahuan, menggunakan informasi secara efektif untuk mencapai tujuan tertentu, mengetahui isu-isu ekonomi, hukum, dan sosial seputar pengguanaan informasi, serta menggunakan informasi secara etis dan legal. Untuk mengetahui kemampuan tersebut pada seorang individu maka dirancanglah berbagai instrumen pengukuran. Instrumen yang telah lebih dahulu dikembangkan dengan cara mengukur secara kognitif kemampuan literasi informasi tersebut. Selanjutnya muncul premis yang menyatakan bahwa faktor psikologis berupa kepercayaan diri juga turut andil menjadi penentu kesuksesan individu dalam menyelesaikan tugas. Melalui premis tersebut muncul argument bahwa kepercayaan diri dapat menjadi ancangan untuk mengukur kompetensi literasi informasi. Dengan mengadopsi disiplin ilmu psikologi disusun dan dikembangkanlah sebuah alternatif pengukuran kemampuan literasi informasi yang disebut Information Literacy SelfEfficacy.
\end{abstract}

Kata kunci: literasi informasi; pengukuran kompetensi; self efficacy

\section{Pendahuluan}

Kegiatan pembelajaran perguruan tinggi merupakan kegiatan pembelajaran orang dewasa. Pembelajaran pada oring dewasa adalah menuntut peserta belajar untuk belajar aktif dan mandiri. Karena ciri orang dewasa dalam kegiatan pembelajaran adalah individu yang mampu mengembangkan diri melalui pendidikan, mengarahkan diri sendiri, dan menjadi guru bagi diri sendiri. Melalui ciri tersebut maka dirancanglah proses kegiatan pembelajaran bagi orang dewasa dengan beberapa langkah yaitu pemberian 
kesempatan untuk berkreasi dan berinisiasi, suasana yang demokratis dalam kegiatan pembelajaran, dan menempatkan peserta belajar sebagai manusia dewasa yang mandiri dan bertanggung jawab.

Perserta pembelajaran di perguruan tinggi adalah mahasiswa. Kegiatan pembelajaran di perguraun tinggi sudah sepatutnya tidak lagi berpusat pada dosen, namun menggeser tanggung jawab dosen kepada mahasiswa (student learning centre). Karakteristik mahasiswa saat ini termasuk karakteristik generasi milenia. Generasi melenia memiliki kebutuhan dan ekspektasi yang sangat berbeda dan kompleks (Sweeney: 2006). Salah satu karakteristik generasi milenia adalah digital native. Digital native secara sederhana didefinisikan sebagai "penutur asli” bahasa digital yaitu individu yang akrab dengan dunia digital dan yang lahir dan tumbuh bersama dengan perkembangan teknologi dan komunikasi, hampir semua aktifitas dalam kehidupannya dikelilingi dengan teknologi digital seperti komputer, jaringan internet, smartphone dan lain sebagainya (Prensky: 2001).

Karakteristik yang dimiliki oleh mahasiswa tersebut menjadi keuntungan bagi mereka ketika menekuni proses pembelajaran orang dewasa. Era informasi kini mengakibatkan mudahnya setiap orang untuk mendapatkan informasi (information is everywhere). Namun kemudaan akses informasi serta banyaknya informasi yang tersedia sebenarnya merupakan peluang dan ancaman bagi mahasiswa, karena tidak semua informasi yang ada adalah informasi yang berkualitas, vaid, dan reliabel, dibutuhkan peran penyortir informasi yang mapu memberikan informasi yang tepat, relevan, dan bermutu bagi mereka. Oleh sebab itu maka dalam proses pembelajaran seorang mahasiswa perlu memiliki bekal dan kompetensi khusus untuk beradaptasi mengatasi ancaman era informasi tersebut. Bekal dan kompetensi tersebut lebih popular dengan istilah literasi informasi.

\section{Literasi Informasi dan Standar Pengukurannya}

Literasi Informasi oleh Boekhorst (2003) didefiniskan melalui 3 konsep, yaitu: ICT concept: mengacu pada kompetensi dalam menggunakan ICT untuk menemukan dan menyebarluaskan informasi. Information Resource conpept: kompetensi menemukan dan menggunakan informasi secara mandiri maupun melalui bantuan perantara. Information Process concept: kompetensi mengenali kebutuhan informasi, menemukan, mengevaluasi, menggunakan, dan menyebarluaskan informasi untuk memperoleh dan menambah pengetahuan baru (tercakup konsep ICT dan IR). Kemudian muncul lagi definisi dari The Chartered Institute of Library and Information Professionals (CILIP: 2005) yang menyatakan bahwa Literasi Informasi merupakan kemampuan untuk Mengenali kapan dan kenapa ia membutuhkan informasi, di mana ia dapat menemukannya, bagaimana ia dapat mengevaluasinya, dan bagaimana mengkomunikasikannya secara etis (Prasetyawan: 2014).

Selanjutnya Association of College and Research Libraries memberikan deskripsi karakteristik mengenai orang yang memiliki kemampuan literasi informasi. Orang yang memiliki kemampuan literasi informasi adalah mereka memiliki kemampuan untuk: Menentukan informasi yang dibutuhkan, Mengakses kebutuhan informasinya secara efektif dan efisien, Mengevaluasi informasi dan sumber-sumber yang didapatkannya secara kritis, Menggabungkan Informasi yang dipilihnya menjadi sebuah landasan 
pengetahuan, Menggunakan informasi secara efektif untuk mencapai tujuan tertentu, Mengetahui isu-isu ekonomi, hukum, dan sosial seputar pengguanaan informasi, serta menggunakan informasi secara etis dan legal. Karakteristik individu yang memiliki kemampuan individu rekomendasi Association of College and Research Libraries kerap dijadikan standar pengukuran kemampuan literasi informasi seorang individu (Prasetyawan: 2014).

Jika membahas mengenai standar pengukuran literasi informasi, terdapat dua standar pengukuran yang kerap dijadikan acuan dan panduan. Yang pertama adalah standar pengukuran literasi informasi yang direkomendasikan oleh AASL (American Association of School Librarians). Sesuai dengan nama organisasinya mereka merekomendasikan 3 kategori literasi informasi khusus bagi siswa sekolah, yaitu kategori 1 literasi informasi, kategori 2 pembelajar mandiri, dan kategori 3 tanggung jawab social. Pada setiap kategori tersebut terdapat sub dan sub-sub kategori yang lebih spesifik. Standar pengukuran literasi informasi yang kedua adalah rekomendasi dari ACRL (Association of College and Research Libraries) yang didesain untuk dikembangkan bagi subjek mahasiswa dan para professional (Stewart, 2011).

Tulisan ini membahas mengenai pengukuran literasi informasi pada pendidikan tinggi, di mana peserta didiknya adalah mahasiswa. Maka standar pengukuran kemampuan literasi informasi yang akan digunakan adalah rekomendasi dari ACRL. Kegiatan pembelajaran di pendidikan tinggi telah menempatkan mahasiswa dalam posisi pembelajar mandiri. Pada era informasi kini sudah sepatutnya para mahasiswa membekali dirinya dengan kemampuan literasi informasi demi suksesnya program pembelajarannya di pendidikan tinggi. Namun bekal tersebut juga belum cukup menjadi kunci suksesnya kegiatan pembelajaran, motivasi dan kepercayaan diri peserta pembelajar menjadi pelengkap suksesnya kegiatan pembelajaran di pendidikan tinggi. Karena kini masyarakat yang hidup di era informasi membutuhkan kepercayaan diri, menjadi pembelajar mandiri, serta dilengkapi dengan kemauan menjadi pembelajar sepanjang hidup (life long learner).

\section{Pentingnya kepercayaan diri (Self-efficacy) pada kemampuan literasi informasi}

Mengutip apa yang telah disampaikan oleh seorang ahli psikologi Bandura (1977) dalam tulisannya yang berjudul "Self-efficacy: toward a unifying theory of behavior change" kesuksesan tidak dapat hanya didasarkan pada kepemilikan ketrampilan tertentu yang dibutuhkan oleh seorang individu, namun juga memerlukan kepercayaan diri untuk menggunakan ketrampilan tersebut secara efektif. Dengan kata lain seorang individu dituntut mampu untuk mengembangkan kepercayaan diri dalam ketrampilan yang mereka pelajari. Oleh karena itu mahasiswa sebagai pembelajar mandiri selain memiliki kemampuan literasi informasi, mereka harus merasa berkompetensi dan percaya diri terhadap kemampuan literasi informasinya (S Serap Kurbanoglu, 2003; Serap S. Kurbanoglu, Akkoyunlu, \& Umay, 2006).

Lebih lanjut lagi Bandura (1997) mendefinisikan self-efficacy adalah keyakinan terhadap kemampuan diri seorang individu untuk mengatur dan melakukan tindakan yang diperlukan untuk mencapai tujuan tertentu. Kepercayaan diri tersebut menjadi pondasi atau dasar bagi seorang individu untuk bertindak. Seorang individu cenderung untuk melakukan tugas atau kegiatan yang mereka merasa percaya 
diri karena memiliki kompetensi, namun menghindari perihal sebaliknya. Self-efficacy menjadi penentu bagi ketangguhan dan kegigihan seorang individu dalam menghadapi kesulitan serta seberapa banyaknya usaha yang mereka lakukan untuk menyelesaikan kesulitan tersebut. Seorang individu dengan self-efficacy yang tinggi memiliki ekspektasi untuk berhasil serta senantiasa bertahan (gigih) dalam melakukan kegiatan sampai tuntas. Sebaliknya seorang individu dengan self-efficacy yang rendah cenderung takut gagal dan selalu menghidari aktifitas yang menantang. Semakin tinggi rasa percaya diri akan keberhasilan, semakin besar pula usaha, ketekunan, dan kegigihan seorang individu (Pajares, 2002; Kear, 2000).

Mahasiswa sebagi peserta didik pendidikan tinggi yang didesain untuk menjadi pembelajar mandiri dituntut untuk memiliki information literacy self-efficacy yang tinggi sebagi bekal menjadi pembelajar sepanjang hayat. Jika seorang mahasiswa memiliki kompetensi dan percaya diri terhadap kemampuan literasi informasinya maka mereka akan gigih dan mudah menyelesaikan permasalahan seputar kebutuhan informasinya. Jika tidak, maka mahasiswa tersebut cenderung akan menghindan dan ragu untuk menylesaikan masalah seputar kebutuhan informasinya (S Serap Kurbanoglu, 2003; Serap S. Kurbanoglu et al., 2006).

\section{Mengukur Kemampuan Literasi Informasi dengan Instrumen Information Literacy Self- Efficacy}

Kajian self-efficacy berakar dari kajian ilmu psikologi yang dipelopori oleh Bandura pada tahun 1977. Kemudian oleh beberapa ahli di bidang keilmuan lain seperti ilmu pendidikan, ilmu computer, dan lain sebagainya mengadopsi dan mengembangkan self-efficacy sesuai dengan konteks keilmuan mereka. Pada tahun 2003 Serap Kurbanoglu seorang ilmuan asal turki tersebut mengenalkan konsep self efficacy serta kaitannya dengan literasi informasi dan belajar sepanjang hayat, yang diterbitkan di Journal of Documentation terbitan Emerald Group. Kemudian pada tahun 2006 di jurnal yang sama dia beserta dua orang rekannya yaitu Akkoyunlu, B., dan Umay, A. mengembangkan model instrumen pengukuran information literacy self-efficacy.

Setelah model instrument pengukuran information literacy self-efficacy dikembangkan dan disempurnakan, maka oleh beberapa peneliti di bidang terkait mulai digunakan untuk mengukur kepercayaan diri terhadap kemampuan literasi informasi individu. Para peneliti tersebut anatara lain adalah, Usluel pada tahun 2007 melalui tulisannya yang berjudul "Can ICT usage make a difference on student teachers' information literacy self-efficacy" menggunakan instrumen information literacy self-efficacy sebagai alat ukur kepercayaan diri terhadap kemampuan literasi informasi. Kemudian Kilic-Cakmak dengan tulisanya yang berjudul "Learning strategies and motivational factors predicting information literacy self-efficacy of e-learner" yang terbit pada tahun 2010. Pada tahun 2013 dan 2016 Ross, Mitchell, Perkins, Helendan Bodey, Kelli juga menggunakan instrumen yang sama untuk penelitiannya yang berjudul Information literacy self-efficacy: The effect of juggling work and study dan Academic motivation and information literacy self-efficacy: The importance of a simple desire to know (Ross, Perkins, \& Bodey, 
2013, 2016). Dalam pengukurannya para peneliti tersebut menggunakan skala likert untuk mengidentifikasi seberapa percaya dirinya seorang mahasiswa terhadap kemampuan literasi informasi yang dimilikinya. Mengutip dari apendik yang ditampilkan oleh penelitian tersebut, berikut adalah 28 poin instrumen information literacy self-efficacy (Serap S. Kurbanoglu et al., 2006).

Saya merasa percaya diri dan berkompetensi untuk:

1. Mengidentifikasi kebutuan informasi yang saya butuhkan

2. Mengidentifikasi berbagai potensi sumber informasi

3. Melakuakan strategi pencarian informasi dengan membatasi pencarian dengan subjek, bahasa, dan waktu.

4. Menginisiasi strategi pencarian informasi menggunakan kata kunci dan Logika Boolean (Boolean Logic)

5. Menentukan di mana dan bagaimana menemukan informasi yang saya butuhkan

6. Menggunakan berbagai sumber informasi tercetak (seperti buku, majalah, ensiklopedia, dan lain sebagaianya)

7. Menggunakan berbagai sumber informasi elektronik

8. Menemukan informasi di perpustakaan

9. Menggunakan katalog perpustakaan

10. Menemukan sumber informasi di perpustakaan menggunakan katalog perpustakaan

11. Menggunakan perangkat pencarian di internet ( seperti mesin pencari, direktori, dan lain sebagainya)

12. Menggunakan berbagai jenis perpustakaan

13. Menggunakan berbagai macam sumber daya informasi pada saat yang sama

14. Menentukan autoritas (kepengarangan), kekinian, dan keandalan sumber informasi

15. Memilih informasi yang tepat untuk kebutuhan informasi

16. Mengidentifikasi poin-poin yang disepakati dan tidak di antara berbagai sumber informasi

17. Mengevaluasi sumber informasi dari website

18. Mensintesa informasi yang baru ditemukan dengan informasi yang ditemukan sebelumnya

19. Menafsirkan informasi visual (misalnya grafik, tabel, dan diagram)

20. Menulis makalah penelitian

21. Menentukan isi dan membentuk bagian-bagian dalam tulisan (seperti pendahuluan, pembahasan, dan kesimpulan) dari presentasi tertulis maupun lisan.

22. Menyiapkan bibliografi

23. Membuat catatan bibliografi dan mengatur daftar pustaka

24. Membuat catatan bibliografi untuk berbagai sumber informasi ( seperti buku, artikel jurnal, makalah, tesis, dan halaman web)

25. Membuat kutipan dan menggunakan kutipan dalam teks 
26. Memilih format ( tertulis, lisan, dan virtual) yang sesuai dengan audien (mahasiswa atau rekan)

27. Belajar dari pengalaman saya dalam memecahkan permasalahan informasi dan meningkatkan ketrampilan literasi informasi saya

28. Mengkritisi kualitas penelusuran informasi saya beserta produk (tulisan) yang dihasilkan

\section{Simpulan}

Mahasiswa telah dianggap dewasa dan mampu secara mandiri untuk mengembangkan diri dalam melakukan kegiatan pembelajaran. Pada era informasi seperti saat ini penting bagi peserta didik pendidikan tinggi (mahasiswa) memiliki kepercayaan diri dan kemampuan literasi informasi. Kepercayaan diri dan kemampuan literasi informasi seorang mahasiswa bukan hanya menjadi bekal bagi mereka ketika menuntut ilmu di pendidikan tinggi. Namun terlebih penting lagi adalah perihal tersebut merupakan bekal bagi mahasiswa menjadi pembelajar sepanjang hayat. Melalui instrumen pengukuran information literacy selfefficacy, perguruan tinggi dalam hal ini diambil peran oleh perpustakaan dapat melakukan evaluasi untuk dilakukan tindak lanjut pelatihan dan pengembangan kemampuan literasi informasi bagi mahasiswa.

\section{Daftar Pustaka}

Bandura, A. (1977). Self-efficacy: toward a unifying theory of behavior change, Psychological Review. Vol. 84, pp. 191-215.

Bandura, A. (1997). Self-efficacy: The Exercise of Control. W.H. Freeman and Company: New York

Boekhorst, A. K. (2003). Becoming information literate in the Netherlands. Library Review, 52 (7), 298 309.

CILIP (2005) Information Literacy: Definition. London: CILIP. Retrieved from http://www.cilip.org.uk/professionalguidance/informationliteracy/definition/

Kear, M. (2000). Concept Analysis of Self-efficacy. Graduate Research in Nursing. available at: http://graduateresearch.com/Kear.htm

Kilic-Cakmak, E. (2010). Learning strategies and motivational factors predicting information literacy selfefficacy of e-learner. Australasian Journal of Educational Technology, 26(2), 192-208

Kurbanoglu, S. S. (2003). Self-efficacy : a concept closely linked to information literacy and lifelong learning, 59(6), 635-646. http://doi.org/10.1108/00220410310506295

Kurbanoglu, S. S., Akkoyunlu, B., \& Umay, A. (2006). Developing the information literacy self efficacy scale. Journal of Documentation, 62(6), 730-743. http://doi.org/10.1108/00220410610714949

Pajares, F. (2002). Overview of Social Cognitive Theory and of Self-efficacy. available at: www.emory.edu/EDUCATION/MFP/eff.html

Prasetyawan, Yanuar Yoga. (2014) "Literasi Informasi dan Peran Pustakawan Sebagai Agen Literasi”, Prosiding : Diskursus Literasi Informasi. Semarang : FPPTI Jawa Tengah, Hlm. 159 165. 
Prensky, Marc. (2001). Digital Natives, Digital Immigrants. available at: http://www.marcprensky.com/writing/prensky\%20\%20digital\%20natives,\%20digital\%20immigran ts\%20-\%20part1.pdf

Ross, M., Perkins, H., \& Bodey, K. (2013). Information literacy self-efficacy : The effect of juggling work and study. Library and Information Science Research, 35(4), 279-287. http://doi.org/10.1016/j.lisr.2013.04.008

Ross, M., Perkins, H., \& Bodey, K. (2016). Academic motivation and information literacy self-efficacy: The importance of a simple desire to know. Library \& Information Science Research, 38(1), 2-9. http://doi.org/10.1016/j.lisr.2016.01.002

Stewart, C. (2011). Measuring Information Literacy: Beyond the Case Study. The Journal of Academic Librarianship, 37(3), 270-272. http://doi.org/10.1016/j.acalib.2011.03.003

Sweeney, Richard T. (December 22, 2006). Millennial Behaviors \& Demographics. available at: http://library1.njit.edu/staff-folders/sweeney/index.htm

Usluel, Y. K. (2007). Can ICT usage make a difference on student teachers' information literacy selfefficacy. Library and Information Science Research, 29,92-102 